\title{
Optimization of Biosorption Performance of Casuarina Leaf Powder for the Removal of Lead Using Central Composite Design
}

\author{
Srinivasa Rao $\mathrm{J}^{1 *}$, Kesava Rao $\mathrm{C}^{2}$ and Prabhakar $\mathbf{G}^{2}$
}

${ }^{1}$ Department of Chemical Engineering, Bapatla Engineering College, Guntur, India

${ }^{2}$ Department of Chemical Engineering, S. V. University, Tirupati, India

\begin{abstract}
Rapid industrialization, urbanization and increase in population have led to increasing the pollution levels. Heavy metal pollution of water is of major concern now-a-days as water is the basic need for mankind. The present investigation is removal of lead from aqueous solutions using a new biosorbent Casuarina leaf powder. The cumulative effects of operating parameters such as initial metal ion concentration, $\mathrm{pH}$ of the aqueous solution, biosorbent dosage and temperature on the lead biosorption were analyzed using Response Surface Methodology (RSM). For obtaining the mutual interaction between the variables and optimizing these variables, a $2^{4}$ full factorial central composite design was employed. According to ANOVA results, the proposed quadratic model for CCD fitted very well to the experimental data. The optimal set of conditions for maximum percentage biosorption of lead is found to be $\mathrm{pH}=4.988$, biosorption dosage $(\mathrm{w})=35.37 \mathrm{~g} / \mathrm{L}$, initial lead concentration $(\mathrm{Co})=18.0555 \mathrm{mg} / \mathrm{L}$ and temperature $=306.47 \mathrm{~K}$ and the $\%$ of biosorption calculated at these values found to be $95.73 \%$. The Langmuir isotherm fitted well with a correlation factor of 0.9944 , followed by Freundlich and Temkin. The entire biosorption process followed pseudo second order kinetics. By applying the Van't Hoff equation the thermodynamic parameters such as enthalpy $\left(\Delta \mathrm{H}^{\circ}\right)$, entropy $\left(\Delta S^{\circ}\right)$ and free energy $\left(\Delta G^{\circ}\right)$ were evaluated which described the biosorption process as spontaneous, irreversible and endothermic in nature. The optimized values obtained through central composite design and one factor at a time process is in good agreement.
\end{abstract}

Keywords: Biosorption; Casuarina leaf powder; Central composite design; Isotherms; Kinetics

\section{Introduction}

Water is no alien to all the living beings upon earth. It has no barrier or bars over constituencies or continents, as it leaves only $1 / 4^{\text {th }}$ of the land of whole ecosystem. The contaminated water may cause anemia, headache, chills, diarrhea and reduction in hemoglobin formation [1]. The influence of pollution on the global environment, through activities such as rapid industrialization, urbanization and mining operations often lead to an increase in the discharge of toxic metals, such as lead, nickel, chromium, cobalt, copper, cadmium etc., into the environment, which results in a contamination of water. These heavy metal contaminants are hazardous to the environment, because they do not naturally degrade [2]. Beyond certain limits, heavy metals are toxic to living organisms and may cause serious hazard to public health [3]. Environmental engineers and scientists are faced with the challenging task to develop appropriate low cost technologies for effluent treatment [4].

Traditional methods for removal of lead ions from solution include chemical precipitation, ion exchange, electrodialysis and membrane separations. All these methods have various disadvantages, specifically, high capital investment and operating cost, incomplete removal, low selectivity and high energy consumption. Therefore, there is a need for a cost effective treatment method that is capable of removing low concentrations of lead from solution For the last decades, biosorption or sorption of contaminants by sorbents of natural origin has gained important credibility due to the good performance and low cost of these complexing materials [5-10]. A multitude of biomass types comprising fungal biomass, bacterial biomass, algae, peat etc., have been studied for their biosorption of metals [11-14]. Agricultural wastes such as tree bark, peanut skin, hull, tobacco, tomato root tissues and plants waste have been used to remove heavy metals from water [15-17].

In view of the above, the authors tried to use a novel biosorbent
Casuarina leaf powder to remove lead from aqueous solutions and report the application of Response Surface Methodology using Central Composite Design to develop a mathematical model and predict the response and check the adequacy of the model. The objectives of the present study include identifying the maximum lead uptake capacity of the Casuarina leaves powder with respect to various governing parameters. In addition, biosorption isotherms were described by using Langmuir, Freundlich and Temkin models and the kinetic experimental data were correlated by the pseudo first and second order kinetic models. Thermodynamics for biosorption of lead on Casuarina leaves powder is also studied and fitted in to Van't Hoff equation.

\section{Experimental Procedure}

\section{Biosorbent}

Casuarina leaves were collected from the surroundings of Bapatla, Guntur. The Casuarina leaves were washed thrice with tap water and once with distilled water in order to remove adhering surface impurities. The leaves were dried in sunlight until all the moisture was evaporated. The crispy Casuarina leaves were then grinded in a ball mill to powder, separated using British Standard Sieves (BSS) and stored in dry air tight packs to prevent moisture penetration and readily used as biosorbent.

*Corresponding author: Srinivasa Rao J, Department of Chemical Engineering, Bapatla Engineering College, Guntur, India, E-mail: Jsrbec@gmail.com

Received January 28, 2013; Accepted February 06, 2013; Published February 08, 2013

Citation: Srinivasa Rao J, Kesava Rao C, Prabhakar G (2013) Optimization of Biosorption Performance of Casuarina Leaf Powder for the Removal of Lead Using Central Composite Design. J Environ Anal Toxicol 3: 166. doi:10.4172/2161. 0525.1000166

Copyright: (C) 2013 Srinivasa Rao J, et al. This is an open-access article distributed under the terms of the Creative Commons Attribution License, which permits unrestricted use, distribution, and reproduction in any medium, provided the original author and source are credited. 


\section{Preparation of metal solutions}

Test solutions containing lead ions were prepared from $\mathrm{Pb}\left(\mathrm{NO}_{3}\right)_{2}$ at different concentrations ranging from $25,50,100,150,200,250 \mathrm{mg} / \mathrm{L}$. The $\mathrm{pH}$ of each test solution was adjusted to the appropriate value by using 0.1 $\mathrm{N} \mathrm{HNO}_{3}$ or $0.1 \mathrm{~N} \mathrm{NaOH}$ solutions. All the chemicals used in preparing the stocks are of analytical grade and the water used is double distilled water prepared from Millipore ELIX-10 unit.

\section{Batch sorption studies}

The biosorption was carried out in a batch process by contacting a pre-weighed amount of the Casuarina leaves powder with a known volume of aqueous solution. Experiments were conducted in $250 \mathrm{ml}$ Erlenmayer flasks containing $50 \mathrm{ml}$ of $20 \mathrm{mg} / \mathrm{L}$ metal solution using single step optimization procedure. The flasks containing aqueous solution and biosorbent were agitated on an orbital shaker at $180 \mathrm{rpm}$ and samples were taken at predetermined time intervals $(1,3,5,10$, $15,20,25,30,40,50,60,90,120,150$ and $180 \mathrm{~min}$ ) and centrifuged at $14000 \mathrm{rpm}$ and the supernatant liquid was analyzed in Atomic Absorption Spectrophotometer (AAS) - Shimadzu make AA-6300 for final concentrations. Similarly the other variables were varied for a wide range: Biosorbent Size (63, 75 and $105 \mu \mathrm{m}), \mathrm{pH}$ of the aqueous solution (2, 3, 4, 5, 6, 7 and 8), Initial concentration of lead solution (20, $50,80,120$ and $150 \mathrm{mg} / \mathrm{L})$, Biosorbent dosage $(5,10,15,20,25,30,35$, 40 and $50 \mathrm{~g} / \mathrm{L}$ ) and Temperature $(283,293,303,313$ and $323 \mathrm{~K})$.

\section{Process optimization}

Final experimental runs for optimization were obtained through Response Surface Methodology using Central Composite Design with $2^{4}$ factorial runs, 6-central points and 8 -axial points. Design of Experiments (DoE) obtained based on the above optimization technique using STATISTICA software. The extent of biosorption of lead calculated at the preliminary optimum conditions is verified with the final runs for the optimum conditions. For the optimization of biosorption, the regression equation is written in terms of \% biosorption of lead $(\mathrm{Y})$ as function of the parameters having greater influence over the response i.e. $\mathrm{pH}\left(\mathrm{X}_{1}\right)$, Co $\left(\mathrm{X}_{2}\right), \mathrm{w}\left(\mathrm{X}_{3}\right)$, and $\mathrm{T}\left(\mathrm{X}_{4}\right)$. Based on experimental runs and predicted values proposed by $\mathrm{CCD}$ design, the following equation represents multiple regression analysis of the experimental data for the biosorption of lead:

$$
\mathrm{Y}=\mathrm{b}_{0}+\mathrm{b}_{1} \mathrm{x}_{1}+\mathrm{b}_{2} \mathrm{x}_{2}+\mathrm{b}_{3} \mathrm{x}_{3}+\mathrm{b}_{4} \mathrm{x}_{4}+\mathrm{b}_{11} \mathrm{x}_{1}^{2}+\mathrm{b}_{22} \mathrm{x}_{2}^{2}+\mathrm{b}_{33} \mathrm{x}_{3}^{2}+\mathrm{b}_{12} \mathrm{x}_{1} \mathrm{x}_{2}+\mathrm{b}_{13}
$$
$\mathrm{x}_{1} \mathrm{x}_{3}+\mathrm{b}_{23} \mathrm{x}_{2} \mathrm{x}_{3}+\mathrm{b}_{44} \mathrm{x}_{4}^{2}+\mathrm{b}_{14} \mathrm{x}_{1} \mathrm{x}_{4}+\mathrm{b}_{24} \mathrm{x}_{2} \mathrm{x}_{4}+\mathrm{b}_{34} \mathrm{x}_{3} \mathrm{x}_{4}$

\section{Results and Discussion}

\section{Effect of agitation time}

Duration of equilibrium biosorption is defined as the time required for heavy metal concentration to reach a constant value during biosorption. The equilibrium agitation time is determined by plotting the \% biosorption of lead against agitation time as shown in figure 1 for the interaction time intervals between 1 to $180 \mathrm{~min}$. For $63 \mu \mathrm{m}$ size of $10 \mathrm{~g} / \mathrm{L}$ biosorbent dosage mixed in $50 \mathrm{~mL}$ of aqueous solution $\left(\mathrm{C}_{\mathrm{o}}=20 \mathrm{mg} / \mathrm{L}\right), 50.4 \%$ of lead is biosorbed in the first one minute and reached to $55.7 \%$ after 5 minutes of biosorption. The \% biosorption is increased briskly up to $60 \mathrm{~min}$ reaching $86.5 \%$. Beyond $60 \mathrm{~min}$, the \% of biosorption is constant indicating the attainment of equilibrium conditions. The maximum biosorption of $86.5 \%$ is attained for $60 \mathrm{~min}$ of agitation time. The rate of biosorption is fast in the initial stages because adequate surface area of the biosorbent is available for the biosorption of lead. As time increases, more amount of lead gets biosorbed onto the surface of the biosorbent due to Vanderwaal's forces of attraction and resulted in decrease of available surface area. The biosorbate, normally, forms a thin one molecule thick layer over the surface. When this monomolecular layer covers the surface, the biosorbent capacity is exhausted. Therefore, all other experiments are conducted at this agitation time.

\section{Effect of biosorbent size}

The variations in \% biosorption of lead from the aqueous solution with biosorbent size are drawn in figure 2 with percentage biosorption of lead as a function of biosorbent size. The percentage of biosorption is decreased from $86.9 \%$ to $80.2 \%$ as the biosorbent size increases from 63 to $105 \mu \mathrm{m}$. This phenomenon is expected, as the size of the particle decreases, surface area of the biosorbent increases; thereby the number of active sites on the biosorbent also increases.

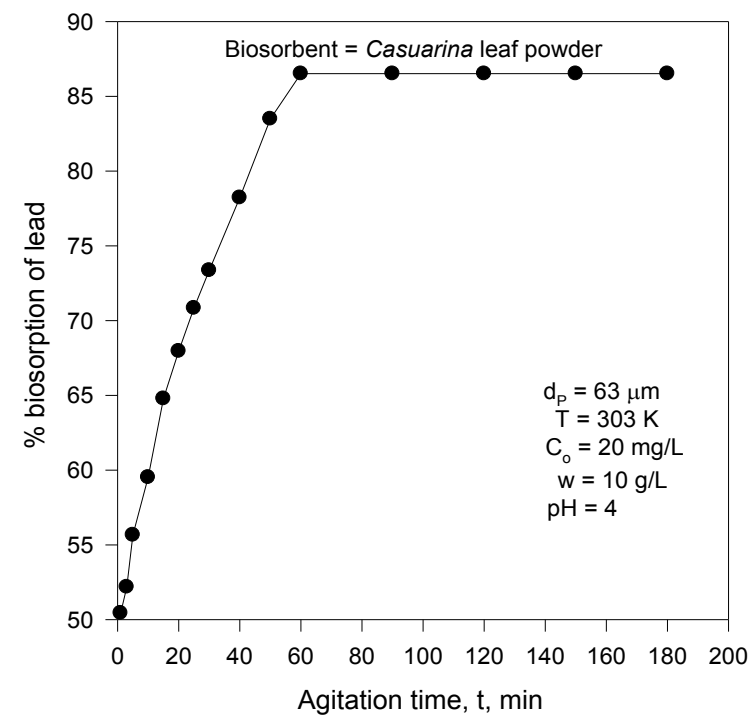

Figure 1: Effect of agitation time on \% biosorption of lead.

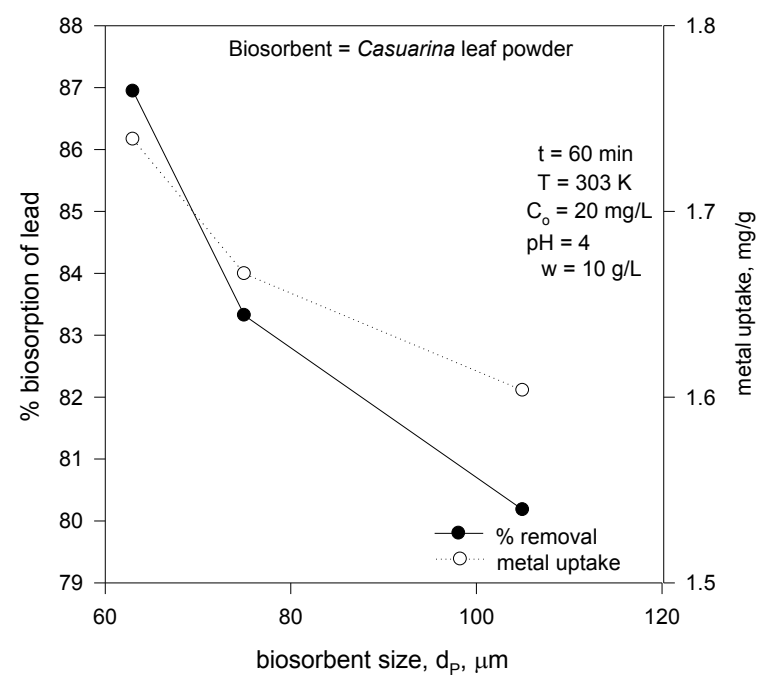

Figure 2: \% Biosorption of lead as a function of biosorbent size. 


\section{Effect of $\mathbf{p H}$}

Biosorption is controlled by $\mathrm{pH}$ by the influence of surface charge of the biosorbent, the degree of ionization and the species of biosorbate. In the present investigation, effect of $\mathrm{pH}$ on lead biosorption is obtained in the $\mathrm{pH}$ range of 2 to 8 of the aqueous solution $(\mathrm{C}=20 \mathrm{mg} / \mathrm{L})$ using $10 \mathrm{~g} / \mathrm{L}$ of $63 \mu \mathrm{m}$ size biosorbent. The effect of $\mathrm{pH}$ of aqueous solution on $\%$ biosorption of lead is shown in figure 3 . The \% biosorption of lead is increased from $64.6 \%$ to $91.4 \%$ as $\mathrm{pH}$ is increased from 2 to 5 and decreased beyond the $\mathrm{pH}$ value of 6 . Percentage of biosorption is decreased to $62.1 \%$ from $84.3 \%$ for $\mathrm{pH}$ variation of 6 to 8 . Since the $\mathrm{pH}$ of aqueous solution influences the solution chemistry of the heavy metals, the binding of metal ions by surface functional groups is strongly $\mathrm{pH}$ dependent. The increase in \% removal when $\mathrm{pH}$ increases from 2 to 5 could be due to decrease in competition between hydrogen ions and metal species for appropriate sites on the biosorbent surface and also by the decrease in positive surface charge on the adsorbent. However, with increasing $\mathrm{pH}$ above 5 lead tends to hydrolyze and precipitate instead of adsorption and adsorbent was deteriorated with accumulation of metal ions, making the true adsorption studies unpredictable.

\section{Effect of initial concentration of lead}

The effect of \% biosorption on initial concentration of lead in the aqueous solution is shown in figure 4 . The percentage biosorption of lead is increased from $73.3 \%$ to $90.1 \%$ with decrease in $\mathrm{C}_{0}$ from 150 $\mathrm{mg} / \mathrm{L}$ to $20 \mathrm{mg} / \mathrm{L}$. Such behavior can be attributed to the increase in the amount of biosorbate to the unchanging number of available active sites on the biosorbent.

\section{Effect of biosorbent dosage}

The percentage biosorption of lead is drawn against biosorbent dosage for $63 \mu \mathrm{m}$ size biosorbent in figure 5. The biosorption of lead increased from $87.2 \%$ to $93.4 \%$ with an increase in biosorbent dosage from 5 to $35 \mathrm{~g} / \mathrm{L}$. Such behavior is obvious because with an increase in biosorbent dosage, the number of active sites available for lead biosorption would be more. The change in percentage biosorption of lead is marginal from $93.4 \%$ to $93.8 \%$ when ' $w$ ' is increased from 35 to $50 \mathrm{~g} / \mathrm{L}$. Hence all other experiments are conducted at $35 \mathrm{~g} / \mathrm{L}$ dosage.

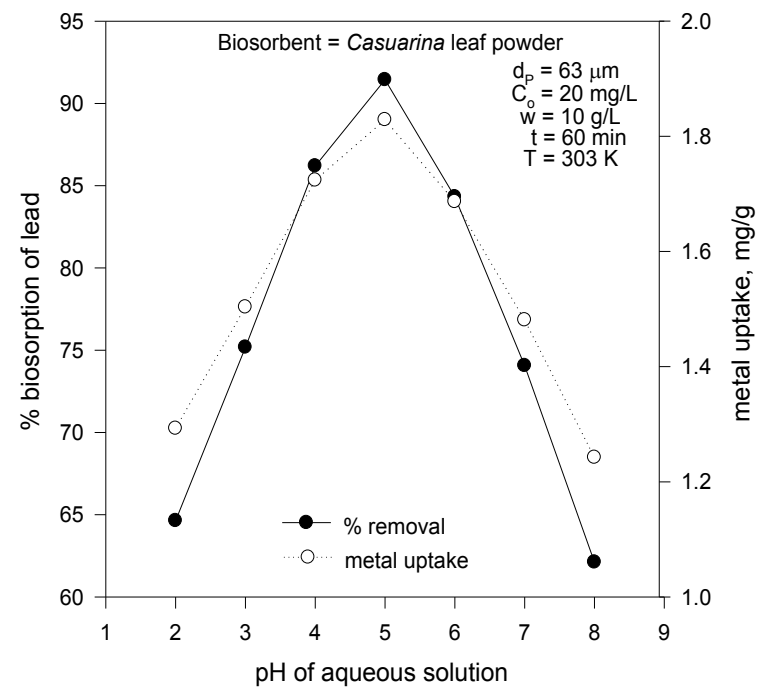

Figure 3: Observation of $\mathrm{pH}$ along with $\%$ biosorption of lead.

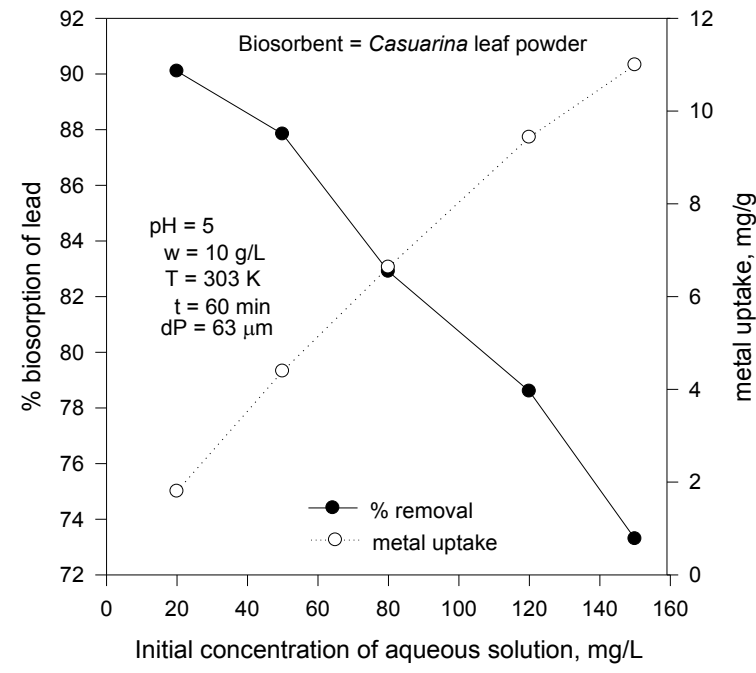

Figure 4: Variation of initial concentration with \% biosorption of lead

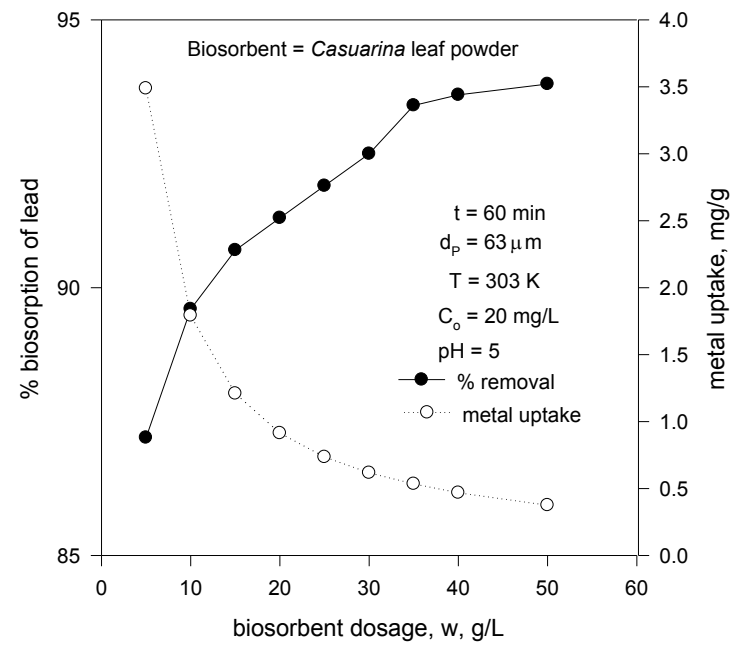

Figure 5: Dependency of \% biosorption of lead on biosorbent dosage.

\section{Effect of temperature}

The effect of temperature on the equilibrium metal uptake was significant. The effect of changes in the temperature on the lead uptake is shown in figure 6. Lead uptake marginally increased from 92.2 to $94.6 \%$ with increasing temperature from $283 \mathrm{~K}$ to $323 \mathrm{~K}$ indicating that the biosorption of lead on to Casuarina leaf powder is endothermic process. Adsorption processes are normally exothermic and as the temperature increases the \% adsorption decreases in accordance with Le Chatelier principle. The reverse phenomena could be activation of non living biomass under moderate temperatures and Increasing the temperature is known to increase the rate of diffusion of the adsorbate molecules across the external boundary layer and in the internal pores of the adsorbent particles, owing to decrease in the viscosity of the solution.

\section{Isotherms}

Langmuir isotherm: Irving Langmuir developed an isotherm 


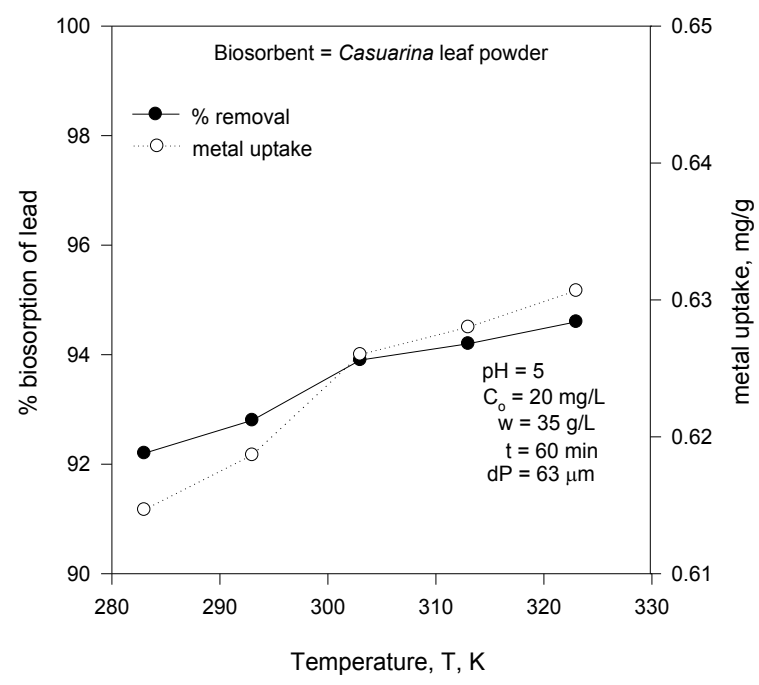

Figure 6: Effect of temperature on \% biosorption of lead.

named Langmuir isotherm. It is the most widely used simple twoparameter equation. The Langmuir relationship is hyperbolic and the equation is:

$$
\mathrm{q}_{\mathrm{e}} / \mathrm{q}_{\mathrm{m}}=\mathrm{bC}_{\mathrm{e}} /\left(1+\mathrm{bC}_{\mathrm{e}}\right)
$$

Equation (5.1) can be rearranged as

$$
\left(\mathrm{C}_{\mathrm{e}} / \mathrm{q}_{\mathrm{e}}\right)=1 /\left(\mathrm{bq}_{\mathrm{m}}\right)+\mathrm{C}_{\mathrm{e}} / \mathrm{q}_{\mathrm{m}}
$$

From the plots between $\left(\mathrm{C}_{\mathrm{e}} / \mathrm{q}_{\mathrm{e}}\right)$ and $\mathrm{C}_{\mathrm{e}}$, the slope $\left\{1 /\left(\mathrm{bq}_{\mathrm{m}}\right)\right\}$ and the intercept $(1 / \mathrm{b})$ are calculated. Further analysis of Langmuir equation is made on the basis of separation factor, $\left(R_{L}\right)$ defined as $R_{L}=1 /\left(1+b C_{e}\right)$.

$0<\mathrm{R}_{\mathrm{L}}<1$ indicates favorable adsorption

$\mathrm{R}_{\mathrm{L}}>1$ indicates unfavorable adsorption

$\mathrm{R}_{\mathrm{L}}=1$ indicates linear adsorption

$\mathrm{R}_{\mathrm{L}}=0$ indicates irrepressible adsorption

Langmuir isotherm is drawn for the present data and shown in figure 7. The equation obtained is $\mathrm{C}_{\mathrm{e}} / \mathrm{q}_{\mathrm{e}}=0.0663142 \mathrm{C}_{\mathrm{e}}+1.0222246$ with a good linearity (correlation coefficient, $\mathrm{R}^{2} \sim 0.9944$ ) indicating strong binding of lead ions to the surface of Casuarina leaf powder. The maximum metal uptake of $\left(\mathrm{q}_{\mathrm{m}}\right) 15.0797 \mathrm{mg} / \mathrm{g}$ is observed and the separation factor obtained $\left(\mathrm{R}_{\mathrm{L}}\right)$ is 0.88617 , indicating favorable biosorption.

Freundlich isotherm: Freundlich presented an empirical biosorption isotherm equation that can be applied in case of low and intermediate concentration ranges. It is easier to handle mathematically in more complex calculations.

The Freundlich isotherm is given by

$$
\mathrm{q}_{\mathrm{e}}=\mathrm{K}_{\mathrm{f}} \mathrm{C}_{\mathrm{e}} \mathrm{n}
$$

Where, $K_{f}(m g)$ represents the biosorption capacity when metal equilibrium concentration and $\mathrm{n}$ represents the degree of dependence of biosorption with equilibrium concentration. The above equation is represented as

$$
\ln \mathrm{q}_{\mathrm{e}}=\ln \mathrm{K}_{\mathrm{f}}+\mathrm{n} \ln \mathrm{C}_{\mathrm{e}}
$$

Freundlich isotherm is drawn between $\ln C_{e}$ and $\operatorname{lnq}_{e}$ (Figure 8). The obtained equation is $\ln _{e}=0.600397 \ln C_{e}+0.274637$; for the present data. The resulting equation has a correlation coefficient of 0.9832 . The ' $n$ ' value $(0.600397)$ in the above equations satisfies the condition of $0<\mathrm{n}<1$ indicating favorable biosorption. The $\mathrm{K}_{\mathrm{f}}$ obtained was 1.882075 .

Temkin isotherm: Temkin and Pyzhev isotherm equation describes the behavior of many biosorption systems on the heterogeneous surface and it is based on the following equation

$$
\mathrm{q}_{\mathrm{e}}=\mathrm{RT} \ln \left(\mathrm{A}_{\mathrm{T}} \mathrm{C}_{\mathrm{e}}\right) / \mathrm{b}_{\mathrm{T}}
$$

The linear form of Temkin isotherm can be expressed as

$$
\mathrm{q}_{\mathrm{e}}=\left(\mathrm{RT} / \mathrm{b}_{\mathrm{T}}\right) \ln \left(\mathrm{A}_{\mathrm{T}}\right)+\left(\mathrm{RT} / \mathrm{b}_{\mathrm{T}}\right) \ln \left(\mathrm{C}_{\mathrm{e}}\right)
$$

The present data are analysed according to the linear form of Temkin isotherm and the linear plot is shown in figure 9. The equation obtained for lead biosorption is: $\mathrm{q}_{e}=3.07614 \ln \mathrm{C}_{\mathrm{e}}-0.7570$ with a

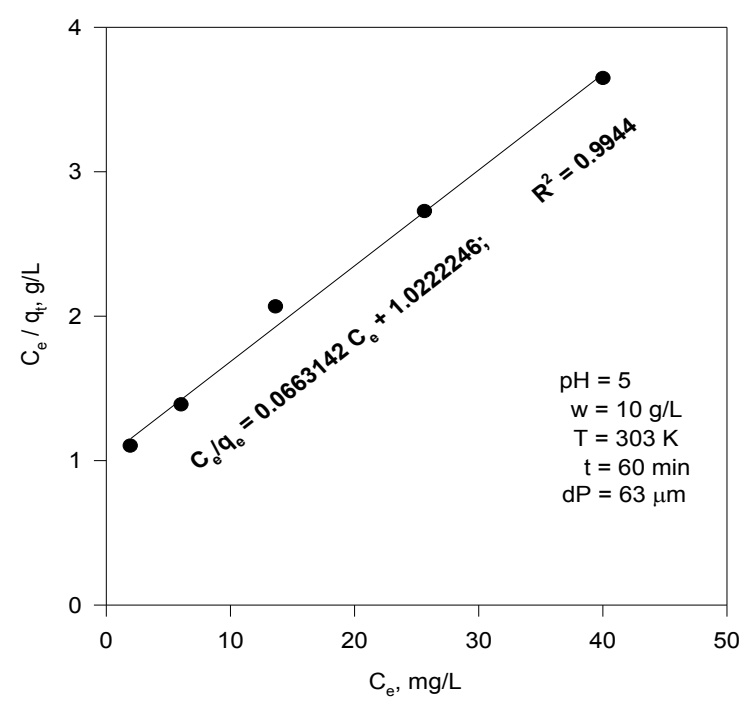

Figure 7: Langmuir isotherm for biosorption of lead.

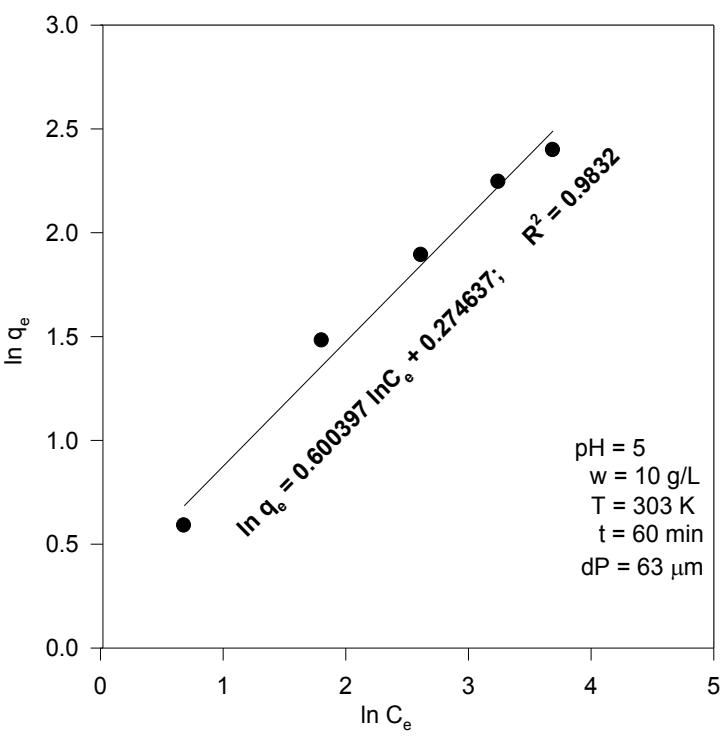

Figure 8: Freundlich isotherm for biosorption of lead. 


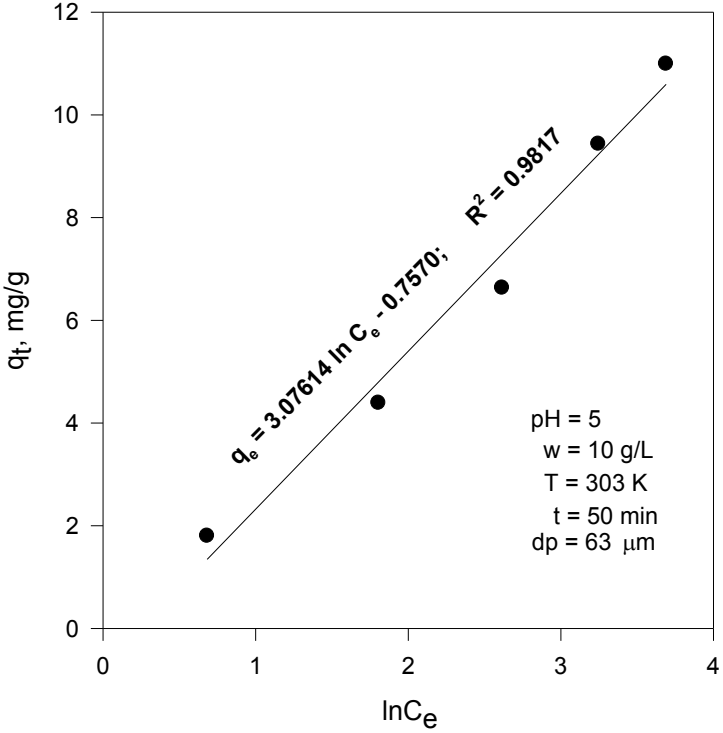

Figure 9: Temkin isotherm for biosorption of lead.

correlation coefficient 0.9817 . The best fit model is determined based on the linear regression correlation coefficient $\left(\mathrm{R}^{2}\right)$. From the figure $7-9$, it is found that biosorption data are well represented by Langmuir isotherm with higher correlation coefficient of 0.9944 , followed by and Freundlich and Temkin isotherms with correlation coefficients of 0.9832 and 0.9817 respectively. The validity of Langmuir model suggests the adsorption process is monolayer and adsorption of each molecule has equal activation energy. The isotherm constants are given in table 1.

\section{Kinetics}

The order of biosorbate - biosorbent interactions have been described using kinetic model. Traditionally, the first order model of Lagergren finds wide application. In the case of biosorption preceded by diffusion through a boundary, the kinetics in most cases follows the first order rate equation of Lagergren:

$$
\left(\mathrm{dq}_{\mathrm{t}} / \mathrm{dt}\right)=\mathrm{K}_{\mathrm{ad}}\left(\mathrm{q}_{\mathrm{e}}-\mathrm{q}_{\mathrm{t}}\right)
$$

Where, $\mathrm{q}_{\mathrm{e}}$ and $\mathrm{q}_{\mathrm{t}}$ are the amounts adsorbed at $\mathrm{t}$, min and equilibrium time and $\mathrm{K}_{\mathrm{ad}}$ is the rate constant of the lagergren first order biosorption.

The above equation can be presented as

$\int\left(\mathrm{dq}_{\mathrm{t}} /\left(\mathrm{q}_{\mathrm{e}}-\mathrm{q}_{\mathrm{t}}\right)\right)=\int \mathrm{K}_{\mathrm{ad}} \mathrm{dt}$

Applying the initial condition $\mathrm{q}_{\mathrm{t}}=0$ at $\mathrm{t}=0$, we get

$\log \left(\mathrm{q}_{\mathrm{e}}-\mathrm{q}_{\mathrm{t}}\right)=\log \mathrm{q}_{\mathrm{e}}-\left(\mathrm{K}_{\mathrm{ad}} / 2.303\right) \mathrm{t}$

Plot of $\log \left(\mathrm{q}_{\mathrm{e}}-\mathrm{q}_{\mathrm{t}}\right)$ versus' $\mathrm{t}$ ' gives a straight line for first order kinetics, facilitating the computation of adsorption rate constant $\left(\mathrm{K}_{\mathrm{ad}}\right)$.

The pseudo second order kinetic equation given below:

$\left(\mathrm{dq}_{\mathrm{t}} / \mathrm{dt}\right)=\mathrm{K}\left(\mathrm{q}_{\mathrm{e}}-\mathrm{q}_{\mathrm{t}}\right) 2$

Where, ' $\mathrm{K}$ ' is the second order rate constant.

Substituting these values in above equation, we obtain:

$1 /\left(\mathrm{q}_{\mathrm{e}}-\mathrm{q}_{\mathrm{t}}\right)=\mathrm{Kt}+\left(1 / \mathrm{q}_{\mathrm{e}}\right)$
Rearranging the terms, we get the linear form as:

$$
\left(\mathrm{t} / \mathrm{q}_{\mathrm{t}}\right)=\left(1 / \mathrm{Kq}_{\mathrm{e}}{ }^{2}\right)+\left(1 / \mathrm{q}_{\mathrm{e}}\right) \mathrm{t}
$$

The pseudo second order model based on above equation, considers the rate -limiting step as the formation of chemisorptive bond involving sharing or exchange of electrons between the biosorbate and biosorbent. If the pseudo second order kinetics is applicable, the plot of $\left(t / q_{t}\right)$ versus' $t$ ' gives a linear relationship that allows computation of $\mathrm{q}_{e}$ and $\mathrm{K}$. The first order and the second order kinetics plots are given in figures 10 and 11 respectively. The rate equations obtained and comparative lead uptake capacities are given in table 2 and table 3 respectively. The correlation coefficients indicate that the system under consideration is more appropriately described by pseudo-second order model. The regression coefficient of 0.9897 shows that that the model can be applied for the entire adsorption process. The confirmation of pseudo second order kinetics indicates that in the adsorption process, concentrations of both adsorbent and adsorbate are involved in rate determining step. In the range of studied parameters, the metal uptake is very good for Casuarina leaf powder.

\section{Thermodynamics of biosorption}

Biosorption is temperature dependant. In general, the temperature dependence is associated with three thermodynamic parameters namely change in enthalpy of biosorption $(\Delta \mathrm{H})$, change in entropy of biosorption $(\Delta \mathrm{S})$ and change in Gibbs free energy $(\Delta \mathrm{G})$. Enthalpy is the most commonly used thermodynamic function due to its practical significance. The negative value of $\Delta \mathrm{H}$ will indicate the exothermic/ endothermic nature of biosorption and the physical/chemical in nature of sorption. It can be easily reversed by supplying the heat equal to calculated $\Delta \mathrm{H}$.

The $\Delta \mathrm{H}$ is related to $\Delta \mathrm{G}$ and $\Delta \mathrm{S}$ as

\begin{tabular}{|l|l|l|}
\hline Langmuir & Freundlich & Temkin \\
\hline $\mathrm{q}_{\mathrm{m}}=15.0797$ & $\mathrm{k}_{\mathrm{f}}=1.882075$ & $\mathrm{~A}_{\mathrm{T}}=0.781859$ \\
\hline $\mathrm{b}=0.06487$ & $\mathrm{n}=0.600397$ & $\mathrm{~b}_{\mathrm{T}}=818.9295$ \\
\hline $\mathrm{R}^{2}=0.9944$ & $\mathrm{R}^{2}=0.9832$ & $\mathrm{R}^{2}=0.9817$ \\
\hline
\end{tabular}

Table 1: Isotherms constants.

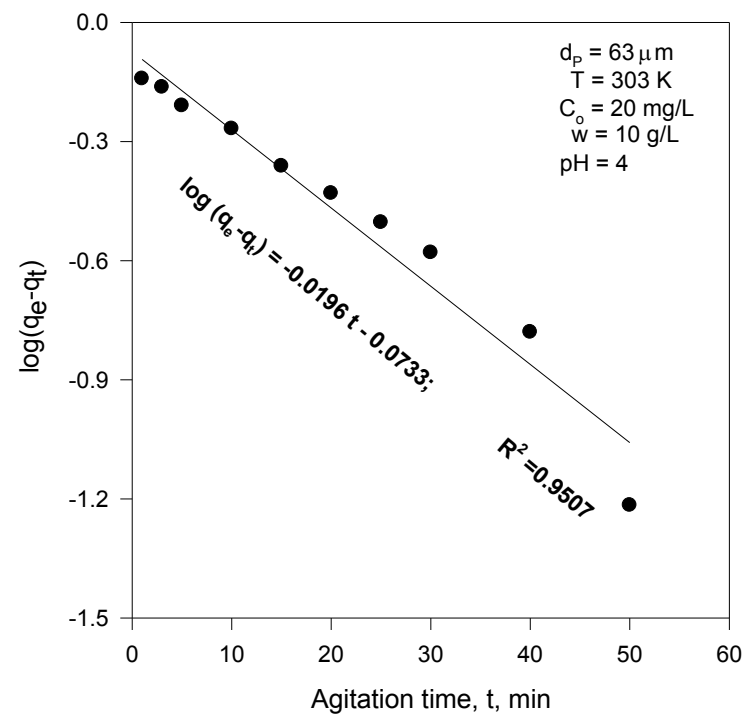

Figure 10: First order kinetics for biosorption of lead. 
Citation: Srinivasa Rao J, Kesava Rao C, Prabhakar G (2013) Optimization of Biosorption Performance of Casuarina Leaf Powder for the Removal of Lead Using Central Composite Design. J Environ Anal Toxicol 3: 166. doi:10.4172/2161-0525.1000166

Page 6 of 9

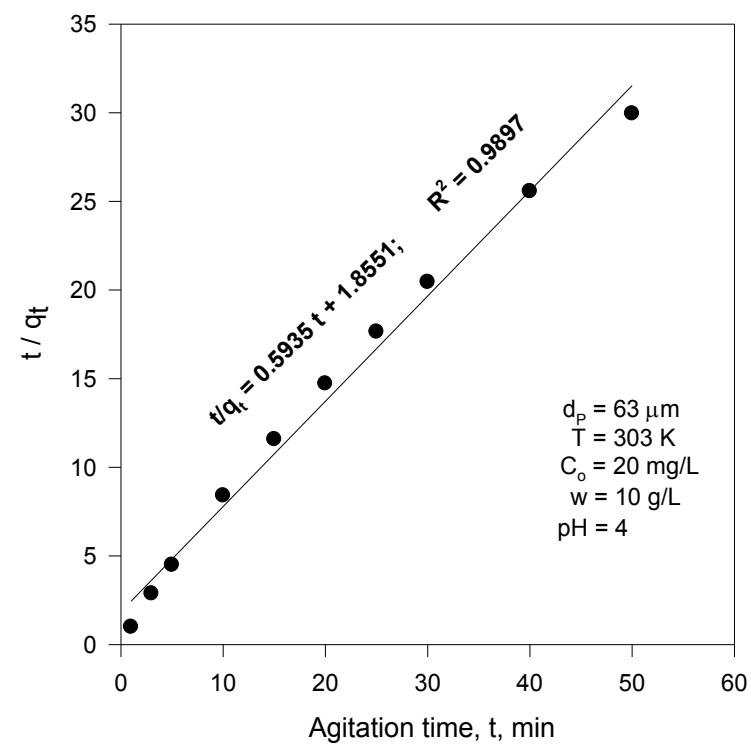

Figure 11: Second order kinetics for biosorption of lead.

\begin{tabular}{|l|l|l|l|}
\hline Order & Equation & K, $\mathbf{~ m i n}^{-1}$ & $\boldsymbol{R}^{\mathbf{2}}$ \\
\hline First order & $\log \left(\mathrm{q}_{\mathrm{e}}-\mathrm{q}_{\mathrm{t}}\right)=-0.019698 \mathrm{t}-0.073348$ & 0.04513 & 0.9507 \\
\hline Second order & $\mathrm{t} / \mathrm{q}_{\mathrm{t}}=0.5935 \mathrm{t}+1.85514$ & 0.18987 & 0.9897 \\
\hline
\end{tabular}

Table 2: Rate Equations and coefficients for biosorption of lead on Casuarina leaf powder.

\begin{tabular}{|l|l|l|}
\hline Authors & Biosorbent & $\mathbf{q}_{\mathbf{t}}, \mathbf{m g} / \mathbf{g}$ \\
\hline S.A. Abo-El-Enein [18] & rice husk ash & 158 \\
\hline Erdal Kenduzler [19] & Amberlyst 36 & 88 \\
\hline Vijayaraghavan [20] & Sargassum & 20.2 \\
\hline Fuat Guzel [21] & black carrot & 5.003 \\
\hline Mustafa Tuzen [22] & Pseudomonas aeruginosa & 5.83 \\
\hline Present investigation & Casuarina leaf powder & 15.0797 \\
\hline
\end{tabular}

Table 3: Lead uptake capacities for different biosorbents.

$$
\Delta \mathrm{G}=\Delta \mathrm{H}-\mathrm{T} \Delta \mathrm{S}
$$

$\Delta \mathrm{S}<1$ indicates that biosorption is impossible whereas $\Delta \mathrm{S}>1$ indicates that the biosorption is possible. $\Delta \mathrm{G}<1$ indicates the feasibility of sorption.

The Vant Hoff's equation is

$$
\begin{aligned}
& \log \left(\mathrm{q}_{\mathrm{e}} / \mathrm{C}_{\mathrm{e}}\right)=\Delta \mathrm{H} /(2.303 \mathrm{RT})+(\Delta \mathrm{S} / 2.303 \mathrm{R}) \\
& \log \left(\mathrm{q}_{\mathrm{e}} / \mathrm{C}_{\mathrm{e}}\right)=-0.40566(1 / \mathrm{T})+1.029489
\end{aligned}
$$

Where, $\left(\mathrm{q}_{\mathrm{e}} / \mathrm{C}_{\mathrm{e}}\right)$ is called the biosorption affinity.

If the value of $\Delta S$ is less than zero, it indicates that the process is highly reversible. If $\Delta S$ is more than or equal to zero, it indicates the reversibility of process. The negative value for $\Delta \mathrm{G}$ indicates the spontaneity of biosorption, whereas the positive value indicates non spontaneity of sorption. Experiments are conducted to understand the biosorption behavior varying the temperature from 283 to $323 \mathrm{~K}$. The Van't Hoff's plot for the biosorption data obtained is shown in figure 12. From the plot the equation obtained is $\log \left(\mathrm{q}_{\mathrm{e}} / \mathrm{C}_{\mathrm{e}}\right)=-0.40566$ $(1 / \mathrm{T})+1.029489$. The values obtained from the equation are $\Delta \mathrm{G}=$ -5964.899, $\Delta \mathrm{H}=7.7672$ and $\Delta \mathrm{S}=19.71177 . \Delta \mathrm{H}$ is positive indicating that the biosorption is endothermic. The negative value of $\Delta \mathrm{G}$ indicates the spontaneity of biosorption. As $\Delta \mathrm{S}$ is more than zero, it indicates the irreversibility of biosorption.

\section{Optimization using Response Surface Methodology (RSM)}

In order to determine an optimum condition for $\mathrm{Pb}$ ions removal, the parameters having greater influence over the response is to be identified. In the present study, the relationship between four independent variables and percent of $\mathrm{Pb}$ ions biosorption fitted well with the quadratic model. Levels of different process variables in coded and un-coded form (Table 4), Results from CCD (Table 5), Analysis of variance (ANOVA) (Table 6), Estimated regression coefficients (Table 7) and Comparison of optimum values obtained from CCD and experimentation (Table 8) for biosorption of lead using Casuarina leaf powder are presented below. For the optimization of biosorption the regression equation: \% biosorption of lead $(\mathrm{Y})$ is function of the

\begin{tabular}{|l|l|l|l|l|l|l|}
\hline \multirow{2}{*}{ Variable } & Name & \multicolumn{9}{|l|}{ Range and levels } \\
\hline & & $-\mathbf{2}$ & $\mathbf{- 1}$ & $\mathbf{0}$ & $\mathbf{1}$ & $\mathbf{2}$ \\
\hline $\mathrm{X}_{1}$ & Biosorbent dosage, $\mathrm{w}, \mathrm{g} / \mathrm{L}$ & 25 & 30 & 35 & 40 & 45 \\
\hline $\mathrm{X}_{2}$ & Initial concentration, $\mathrm{C}, \mathrm{mg} / \mathrm{L}$ & 10 & 15 & 20 & 25 & 30 \\
\hline $\mathrm{X}_{3}$ & $\mathrm{pH}$ of aqueous solution & 3 & 4 & 5 & 6 & 7 \\
\hline $\mathrm{X}_{4}$ & Temperature, $\mathrm{T}, \mathrm{K}$ & 283 & 293 & 303 & 313 & 323 \\
\hline
\end{tabular}

\begin{tabular}{|c|c|c|c|c|c|c|}
\hline \multirow{2}{*}{ Run no. } & \multirow{2}{*}{$X_{1}(w)$} & \multirow{2}{*}{$x_{2}\left(C_{0}\right)$} & \multirow{2}{*}{$\mathrm{X}_{3}(\mathrm{pH})$} & \multirow{2}{*}{$X_{4}(T)$} & \multicolumn{2}{|c|}{$\%$ biosorption of cobalt } \\
\hline & & & & & Experimental & Predicted \\
\hline 1 & -1.0000 & -1.0000 & -1.0000 & -1.0000 & 93.18 & 93.21 \\
\hline 2 & -1.0000 & -1.0000 & -1.0000 & 1.0000 & 93.67 & 93.65 \\
\hline 3 & -1.0000 & -1.0000 & 1.0000 & -1.0000 & 93.19 & 93.18 \\
\hline 4 & -1.0000 & -1.0000 & 1.0000 & 1.0000 & 93.59 & 93.60 \\
\hline 5 & -1.0000 & 1.0000 & -1.0000 & -1.0000 & 92.2 & 92.21 \\
\hline 6 & -1.0000 & 1.0000 & -1.0000 & 1.0000 & 92.79 & 92.82 \\
\hline 7 & -1.0000 & 1.0000 & 1.0000 & -1.0000 & 92.89 & 92.91 \\
\hline 8 & -1.0000 & 1.0000 & 1.0000 & 1.0000 & 93.51 & 93.50 \\
\hline 9 & 1.0000 & -1.0000 & -1.0000 & -1.0000 & 93.8 & 93.78 \\
\hline 10 & 1.0000 & -1.0000 & -1.0000 & 1.0000 & 94.17 & 94.20 \\
\hline 11 & 1.0000 & -1.0000 & 1.0000 & -1.0000 & 93.29 & 93.31 \\
\hline 12 & 1.0000 & -1.0000 & 1.0000 & 1.0000 & 93.74 & 93.71 \\
\hline 13 & 1.0000 & 1.0000 & -1.0000 & -1.0000 & 91.98 & 92.01 \\
\hline 14 & 1.0000 & 1.0000 & -1.0000 & 1.0000 & 92.62 & 92.60 \\
\hline 15 & 1.0000 & 1.0000 & 1.0000 & -1.0000 & 92.28 & 92.27 \\
\hline 16 & 1.0000 & 1.0000 & 1.0000 & 1.0000 & 92.83 & 92.84 \\
\hline 17 & -2.0000 & 0.0000 & 0.0000 & 0.0000 & 94.34 & 94.30 \\
\hline 18 & 2.0000 & 0.0000 & 0.0000 & 0.0000 & 94.21 & 94.20 \\
\hline 19 & 0.0000 & -2.0000 & 0.0000 & 0.0000 & 94.13 & 94.12 \\
\hline 20 & 0.0000 & 2.0000 & 0.0000 & 0.0000 & 92.28 & 92.25 \\
\hline 21 & 0.0000 & 0.0000 & -2.0000 & 0.0000 & 90.71 & 90.67 \\
\hline 22 & 0.0000 & 0.0000 & 2.0000 & 0.0000 & 90.89 & 90.88 \\
\hline 23 & 0.0000 & 0.0000 & 0.0000 & -2.0000 & 93.77 & 93.73 \\
\hline 24 & 0.0000 & 0.0000 & 0.0000 & 2.0000 & 94.75 & 94.74 \\
\hline 25 & 0.0000 & 0.0000 & 0.0000 & 0.0000 & 95.6 & 95.60 \\
\hline 26 & 0.0000 & 0.0000 & 0.0000 & 0.0000 & 95.6 & 95.60 \\
\hline 27 & 0.0000 & 0.0000 & 0.0000 & 0.0000 & 95.6 & 95.60 \\
\hline 28 & 0.00000 & 0.0000 & 0.0000 & 0.0000 & 95.6 & 95.60 \\
\hline 29 & 0.00000 & 0.0000 & 0.0000 & 0.0000 & 95.6 & 95.60 \\
\hline 30 & 0.00000 & 0.0000 & 0.0000 & 0.0000 & 95.6 & 95.60 \\
\hline
\end{tabular}

Table 4: Levels of different process variables in coded and un-coded form for biosorption of lead using Casuarina leaf powder.

Experimental conditions [Coded Values] and observed response values of central composite design with $2^{4}$ factorial runs, 6- central points and 8- axial points. Agitation time fixed at $60 \mathrm{~min}$ and biosorbent size at $63 \mu \mathrm{m}$

Table 5: Results from CCD for cobalt biosorption by Casuarina leaf powder. 
Citation: Srinivasa Rao J, Kesava Rao C, Prabhakar G (2013) Optimization of Biosorption Performance of Casuarina Leaf Powder for the Removal of Lead Using Central Composite Design. J Environ Anal Toxicol 3: 166. doi:10.4172/2161-0525.1000166

\begin{tabular}{|l|l|l|l|l|l|}
\hline Source of variation & SS & df & Mean square(MS) & F-value & P> F \\
\hline Model & 53.85109 & 14 & 3.8465 & 4649.27 & 0.0000 \\
\hline Error & 0.01241 & 15 & 0.0008273 & & \\
\hline Total & 53.8635 & & & & \\
\hline
\end{tabular}

$\mathrm{df}$, degree of freedom; SS, sum of squares; $\mathrm{F}$, factor $\mathrm{F} ; P$, probability. $R^{2}=0.99977 ; R^{2}$ (adj): 0.99955

Table 6: Analysis of variance (ANOVA) of lead biosorption for entire quadratic model.

\begin{tabular}{|l|l|l|l|l|}
\hline Terms & $\begin{array}{l}\text { Regression } \\
\text { coefficient }\end{array}$ & $\begin{array}{l}\text { Standard error of the } \\
\text { coefficient }\end{array}$ & t-value & $P$-value \\
\hline constant & -280.353 & 5.533036 & -50.669 & 0.000000 \\
\hline$X_{1}$ & 1.233 & 0.047130 & 26.151 & 0.000000 \\
\hline$X_{2}$ & -0.013 & 0.000220 & -61.134 & 0.000000 \\
\hline$X_{3}$ & 0.694 & 0.046155 & 15.036 & 0.000000 \\
\hline$X_{4}$ & -0.024 & 0.000220 & -109.843 & 0.000000 \\
\hline$X_{1}{ }^{*} X_{1}$ & 12.272 & 0.232115 & 52.871 & 0.000000 \\
\hline$X_{2}{ }^{*} X_{2}$ & -1.204 & 0.005492 & -219.326 & 0.000000 \\
\hline$X_{3}{ }^{*} X_{3}$ & 2.071 & 0.033977 & 60.965 & 0.000000 \\
\hline$X_{4}{ }^{*} X_{4}$ & -0.003 & 0.000055 & -61.816 & 0.000000 \\
\hline$X_{1}{ }^{*} X_{2}$ & -0.008 & 0.000288 & -26.511 & 0.000000 \\
\hline$X_{1}{ }^{*} X_{3}$ & -0.022 & 0.001438 & -15.385 & 0.000000 \\
\hline$X_{1}{ }^{*} X_{4}$ & -0.000 & 0.000144 & -0.782 & $0.446215^{a}$ \\
\hline$X_{2}{ }^{*} X_{3}$ & 0.037 & 0.001438 & 25.468 & 0.000000 \\
\hline$X_{2}{ }^{*} X_{4}$ & 0.001 & 0.000144 & 5.998 & 0.000024 \\
\hline$X_{3}{ }^{*} X_{4}$ & -0.000 & 0.000719 & -0.608 & $0.551990^{a}$ \\
\hline
\end{tabular}

ainsignificant $(P \geq 0.05)$

Table 7: Estimated regression coefficients for the lead biosorption onto Casuarina leaf powder

\begin{tabular}{|l|l|l|}
\hline Variable & CCD & Experimental value \\
\hline $\mathrm{pH}$ of aqueous solution & 4.9884 & 5.0 \\
\hline Biosorption dosage, $\mathrm{w}, \mathrm{g} / \mathrm{L}$ & 35.3702 & 35 \\
\hline Initial cobalt concentration, $\mathrm{mg} / \mathrm{L}$ & 18.0555 & 20 \\
\hline Temperature, $\mathrm{K}$ & 306.4727 & 303 \\
\hline \% biosorption & 95.7337 & 93.9 \\
\hline
\end{tabular}

Table 8: Comparison of optimum values obtained from CCD and experimentation.

$\mathrm{pH}\left(\mathrm{X}_{1}\right)$, Co $\left(\mathrm{X}_{2}\right), \mathrm{w}\left(\mathrm{X}_{3}\right)$, and $\mathrm{T}\left(\mathrm{X}_{4}\right)$. Based on experimental runs and predicted values proposed by CCD design.

$Y=-280.353+1.233 X_{1}+0.694 X_{2}+12.272 X_{3}+2.071 X_{4}-0.013$ $X_{1}^{2}-0.024 X_{2}^{2}-1.204 X_{3}^{2}-0.003 X_{4}^{2}$

$-0.008 X_{1} X_{2}+0.022 X_{1} X_{3}+0.000 X_{1} X_{4}+0.037 X_{2} X_{3}+0.001 X_{2} X_{4}+$ $0.000 X_{3} X_{4}$

From the Central Composite Design, the Pareto Chart (Figure 13), Observed Vs Predicted values plot (Figure 14) and Surface contour plot (Figures $15 \mathrm{a}-\mathrm{f}$ ) for biosorption of lead on to Casuarina leaf powder are presented below. The optimal set of conditions for maximum percentage biosorption of lead is $\mathrm{pH}=4.9884$ biosorption dosage $(\mathrm{w})$ $=35.3702 \mathrm{~g} / \mathrm{L}$, initial lead concentration $(\mathrm{Co})=18.0555 \mathrm{mg} / \mathrm{L}$ and temperature $=306.4727 \mathrm{~K}$ and the $\%$ of biosorption calculated at these values found to be $95.73 \%$.

\section{Conclusions}

The analysis of the experimental and theoretical data resulted that the equilibrium agitation time for lead biosorption is 60 minutes. The $\%$ removal of lead from an aqueous solution increases with a decrease in the particle size of the biosorbent and increases with increase in biosorbent dosage. With an increase in the initial concentration of

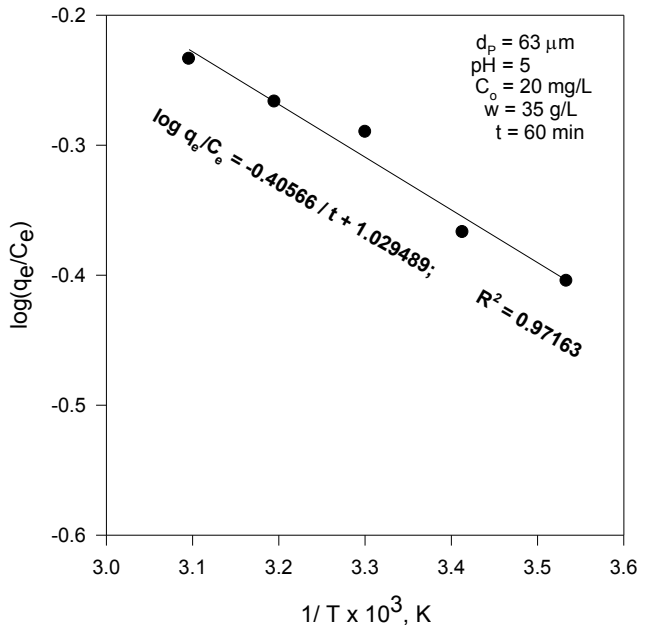

Figure 12: Van't Hoff's plot for biosorption of Lead.

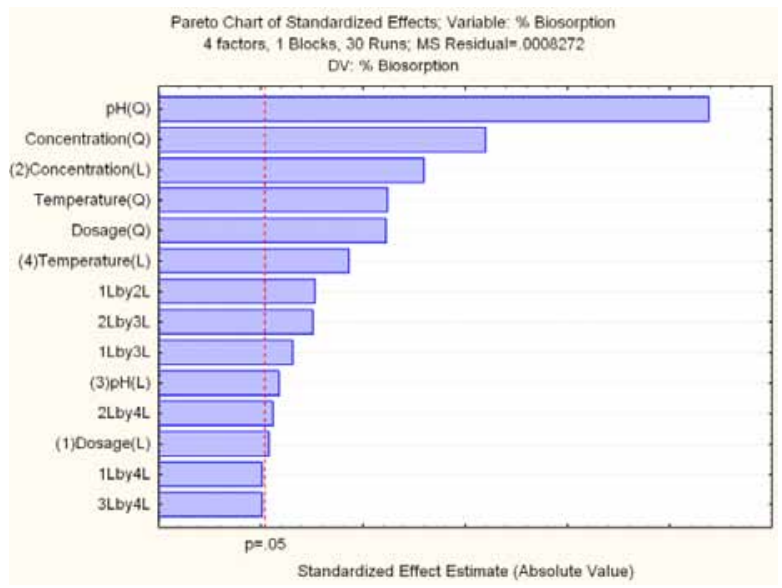

Figure 13: Pareto Chart.

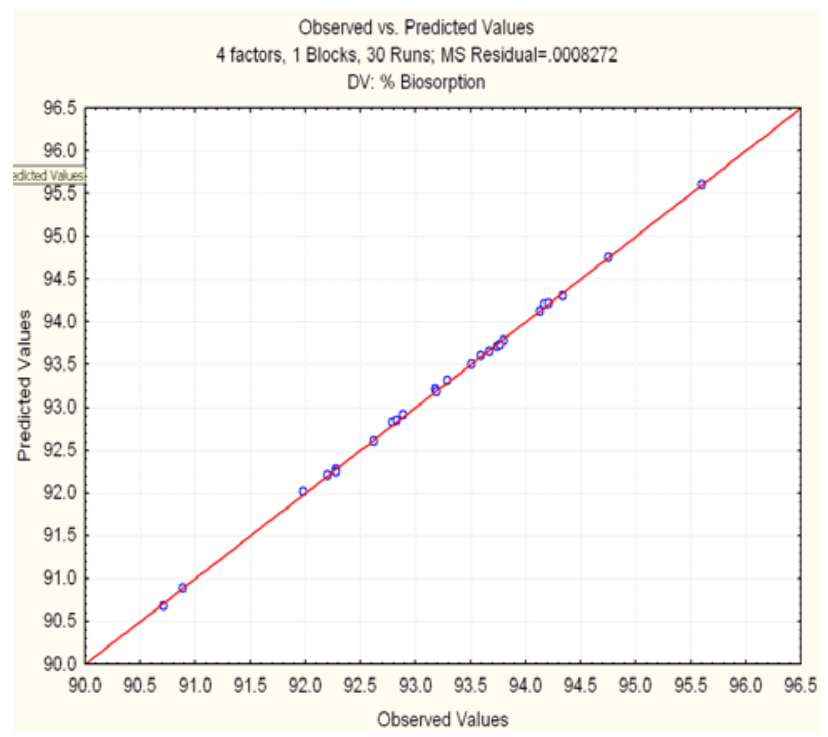

Figure 14: Observed Vs Predicted values plot for \% biosorption of lead. 
Citation: Srinivasa Rao J, Kesava Rao C, Prabhakar G (2013) Optimization of Biosorption Performance of Casuarina Leaf Powder for the Removal of Lead Using Central Composite Design. J Environ Anal Toxicol 3: 166. doi:10.4172/2161-0525.1000166

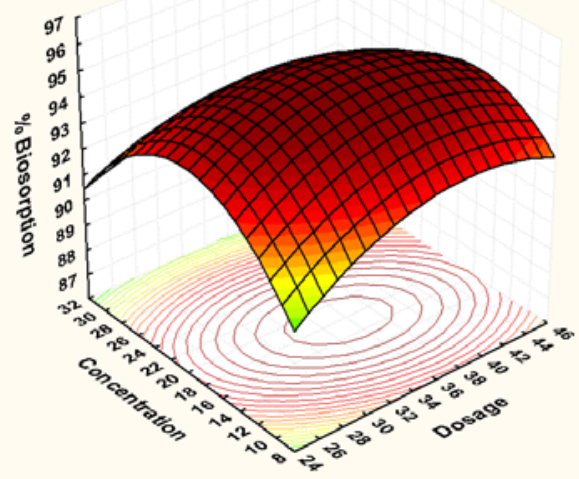

Figure 15a: Surface contour plot for the effects of dosage and concentration of lead on \% biosorption.

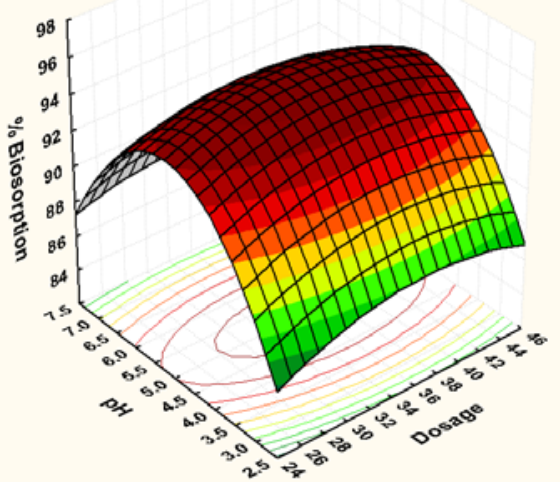

Figure 15b: Surface contour plot for the effects of dosage and $\mathrm{pH}$ on $\%$ biosorption of lead.

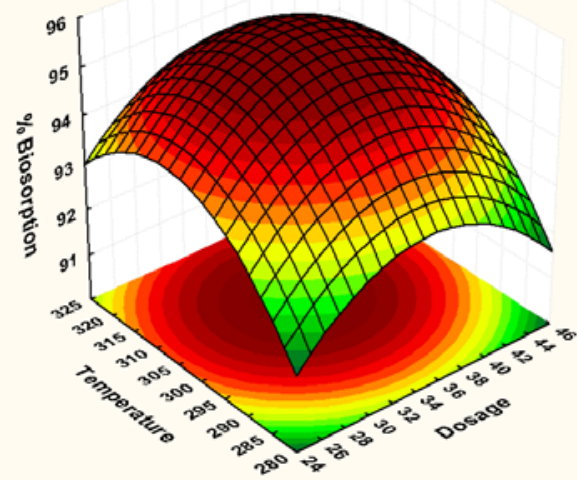

Figure 15c: Surface contour plot for the effects of dosage and temperature on $\%$ biosorption of lead.

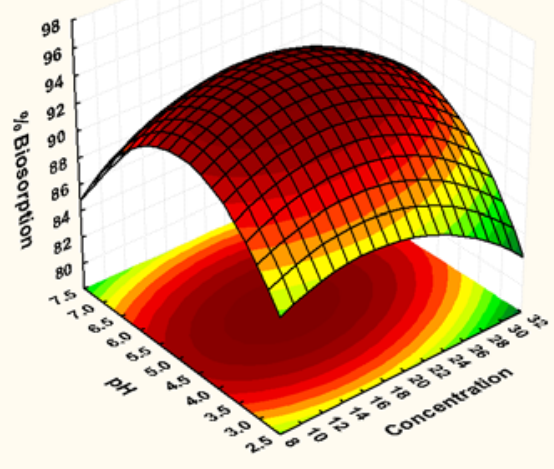

Figure 15d: Surface contour plot for the effects of concentration of lead and $\mathrm{pH}$ on $\%$ biosorption of lead.

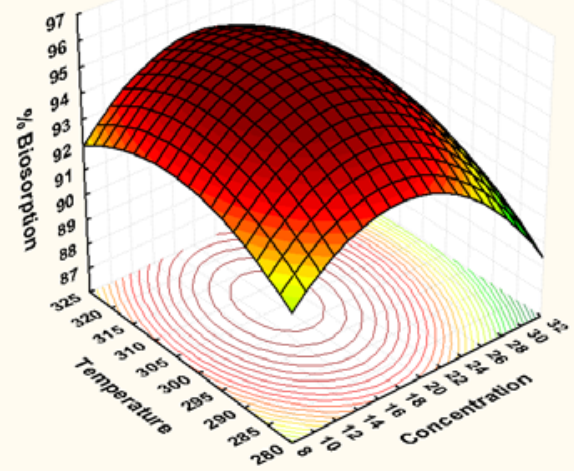

Figure 15e: Surface contour plot for the effects of concentration of lead and temperature on $\%$ biosorption of lead.

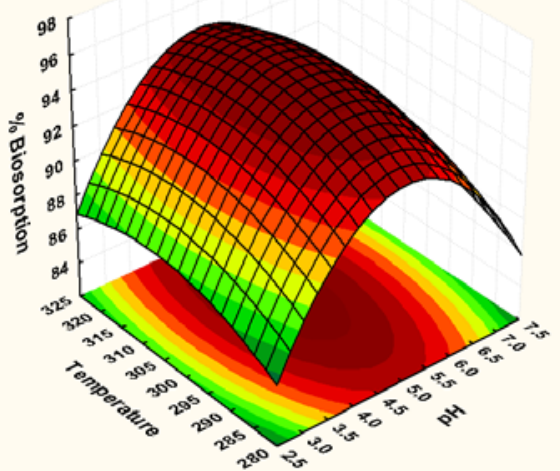

Figure 15f: Surface contour plot for the effects of $\mathrm{pH}$ and temperature on $\%$ biosorption of lead. 
Citation: Srinivasa Rao J, Kesava Rao C, Prabhakar G (2013) Optimization of Biosorption Performance of Casuarina Leaf Powder for the Removal of Lead Using Central Composite Design. J Environ Anal Toxicol 3: 166. doi:10.4172/2161-0525.1000166

lead in the aqueous solution, the percentage removal of lead from the aqueous solution is decreased. Percentage removal of lead from the aqueous solution increases significantly with increase in $\mathrm{pH}$ from 2 to 5 , thereafter percentage removal decreases for further increase in $\mathrm{pH}$. In the range of variables studied, percentage removal is increased from $50.44 \%$ to $93.9 \%$. The maximum uptake capacity of 15.0797 $\mathrm{mg} / \mathrm{g}$ is obtained at temperature $303 \mathrm{~K}$. The kinetic studies show that the biosorption of lead is better described by pseudo second order kinetics It is also found that the data are well represented by Langmuir isotherm with higher correlation coefficient of 0.9944 , followed by Freundlich and Temkin isotherms. The biosorption of lead on to Casuarina leaf powder is irreversible, spontaneous and endothermic in nature. The present study involves the use of statistical experimental design to optimize process conditions for maximal biosorption of lead from aqueous solution using CCD involving RSM. The maximum biosorption of lead (95.73\%) onto Casuarina leaf powder is observed when the processing parameters are set as follows: $\mathrm{pH}=4.988, \mathrm{w}=$ $35.37 \mathrm{~g} / \mathrm{L}, \mathrm{C}_{\mathrm{o}}=18.0555 \mathrm{mg} / \mathrm{L}$ and $\mathrm{T}=306.47 \mathrm{~K}$. Therefore the above said Casuarina leaf powder is effective and efficient biosorbent and is capable of removing lead.

\section{Acknowledgements}

The authors wholeheartedly thank the Bapatla Engineering College and TEQIP-World Bank for supporting the authors and sparing the equipment for Research Purpose.

\section{References}

1. Yan C, Li G, Xue P, Wei Q, Li Q (2010) Competitive effect of Cu(II) and Zn(II) on the biosorption of lead(II) by Myriophyllum spicatum. Hazard waste hazard 179: 721-728.

2. El-Naas MH, Al-Rub FA, Ashour I, Marzouqi M AL (2007) Effect of competitive interference on the biosorption of lead(II) by Chlorella vulgaris. Chem Eng Process 46: 1391-1399.

3. Dursun AY (2006) A comparative study on determination of the equilibrium, kinetic and thermodynamic parameters of biosorption of copper(II) and lead(II) ions onto pretreated Aspergillus niger. Biochemical Eng J 28: 187-195.

4. Ahluwalia SS, Goyal D (2007) Microbial and plant derived biomass for removal of heavy metals from wastewater. Bioresource Technol 98: 2243-2257.

5. Bailey SE, Olin TJ, Bricka RM, Adrian DD (1999) A review of potentially lowcost sorbents for heavy metals. Water Res 33: 2469-2479.

6. Roberts EJ, Rowlnd SP (1973) Removal of mercury from aqueous solutions by nitrogen-containing chemically modified cotton. Environ Sci Technol 7: 552 555
7. Roy D, Greenlaw PN, Shane BN (1993) Adsorption of heavy metals by green algae and ground rice hulls. J Environ Sci Health 28: 37.

8. Srivastava SL, Singh AK, Sharma A (1994) Studies on the uptake of lead and zinc by lignin obtained from black liquor - a paper industry waste material. Environ Technol 15: 353-361.

9. Ozer A, Tumen F, Bildik M (1997) $\mathrm{Cr}$ (III) Removal from Aqueous Solutions by Depectinated Sugar Beet Pulp. Environ Technol 18: 893-901.

10. Niu H, Xu XS, Wang JH (1993) Removal of lead from aqueous solutions by Penicillium Biomass. Biotechnol Bioeng 49: 785-787.

11. Kuyucak N, Volesky B (1990) Biosorption by algal biomass, Biosorption of heavy metals B. Volesky, (CRC Press, Boca Raton, FL, 1990) 173-198.

12. Ferguson J, Bubela $B(1974)$ The concentration of $\mathrm{Cu}(\mathrm{II}), \mathrm{Pb}(\mathrm{II})$, and $\mathrm{Zn}$ (II) from aqueous solutions by particulate algae matter. Chem Geol 13: 163-186.

13. Ho YS, Wase DAJ Forster CF (1995) Batch nickel removal from aqueous solution by sphagnum moss peat. Water Res 29: 1327-1332.

14. Chen XH, Gosset T, Thevenot DR (1990) Batch copper ion binding and exchange properties of peat. Water Res $24: 1463-1471$

15. Randall JM, Hantala E (1975) Removing heavy metal ions from water. U.S Patent 3925192

16. Scott CD (1992) Removal of dissolved metals by plant tissue. Biotechno Bioeng 39: 1064-1068.

17. Lujan JR, Darnal DW, Stark PC, Rayson GD, Gardea_Torresdey LG (1994) Metal ion binding by algae and higher plant tissues. A phenomenological Study of solution pH Dependence. Solvent Extr Ion Exc 12: 803-816.

18. Abo-El-Enein SA, Eissa MA, Diafullah AA, Rizk MA, Mohamed FM (2009) Removal of some heavy metals ions from wastewater by copolymer of iron and aluminum impregnated with active silica derived from rice husk ash. J Hazard Mater 172: $574-579$

19. ErdalKenduzler A, RehberTurker and O zcanYalcınkaya (2006) Separation and preconcentration of trace lead from various samples with Amberlyst 36 column and determination by flame atomic absorption spectrometry. Talanta 69: 835-840.

20. Vijayaraghavan K, Teo TT, Balasubramanian R, Joshi UM (2009) Application of Sargassum biomass to remove heavy metal ions from synthetic multi-metal solutions and urban storm water runoff. J Hazard Mater 164: 1019 -1023.

21. Guzel F, Yakut H, Topal G (2008) Determination of kinetic and equilibrium parameters of the batch adsorption of $\mathrm{Mn}(\mathrm{II}), \mathrm{Co}(\mathrm{II}), \mathrm{Ni}(\mathrm{II})$ and $\mathrm{Cu}(\mathrm{II})$ from aqueous solution by black carrot (Daucuscarota L.) residues. J HazardMate 153: $1275-1287$

22. Tuzen M, Saygi KO, Usta C, Soylak M (2008) Pseudomonas aeruginosa immobilized multiwalled carbon nanotubes as biosorbent for heavy metal ions. Bioresource Technol 99: 1563-1570. 